\title{
Peningkatan Sistem Imunitas Keluarga di Masa New Normal melalui Konsumsi Kerang-Kerangan dan Diversifikasi Pengolahannya bagi Masyarakat Pesisir Pantai Mutiara
}

\author{
Lucky Hartanti $^{1}$, Asri Mulya Azhari ${ }^{1}$, Warsidah ${ }^{2}$, Mega Sari Juane Sofiana ${ }^{2}$, Shifa \\ Helena*2

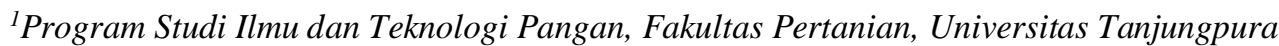 \\ ${ }^{2} J u r u s a n$ Ilmu Kelautan, Fakultas MIPA, Universitas Tanjungpura \\ * Correspondent Author: shifahelena@fmipa.untan.ac.id
}

\begin{abstract}
ABSTRAK
Kerang-kerangan adalah salah satu komoditas perairan tawar dan laut dengan dengan kelezatan dan kandungan nutrisi yang tinggi sehingga diminati sebagai konsumsi masyarakat. Pantai Mutiara merupakan salah satu wilayah pesisir di wilayah Kayong Utara dengan potensi hasil laut yang sangat besar, khususnya kekerangan. Pemanfaatan kekerangan sebagai pangan fungsional yang dapat dijadikan sebagai makanan peningkat imunitas tubuh dalam masa pandemi Covid19 ataupun di masa new normal belum optimal, demikian juga dengan pengolahan kerang yang selain memenuhi kebutuhan juga dapat dijadikan sebagai obyek dagangan. Kegiatan Pengabdian kepada Masyarakat (PKM) bertujuan untuk mensosialisaikan makanan kekerangan sebagai bahan pangan yang sangat berperan dalam meningkatkan system imunitas tubuh sehingga dapat terhindar dari penyakit terutama infeksi virus Covid 19, sekaligus menambah keterampilan peserta dalam mengolah berbagai jenis kekerangan untuk konsumsi keluarga. Metode kegiatan ini adalah dengan ceramah edukatif tentang manfaat mengkonsumsi kekerangan terhadap kesehatan dan praktek mengolah kekerangan sebagai lauk untuk konsumsi keluarga. Kegiatan ini dihadiri oleh 15 peserta terdiri dari ibu rumah tangga dan putri remaja, yang antusias mengikuti kegiatan dari ceramah ilmiah edukatif sampai dengan praktek membuat aneka olahan lauk dari kerang darah(Anadara granosa) dan kerang bambu (Solen sp). Evaluasi kegiatan dilakukan dengan memberikan soal pretest dan post test, menunjukkan bahwa pemahaman materi oleh peserta kegiatan mengalami kenaikan dari persentase $30-45 \%$ menjadi $80-90 \%$.
\end{abstract}

Kata Kunci: Covid-19, Diversifikasi, Imunitas, Kerang, Pangan Fungsional

Received: July 8, 2021

Revised: August 10, 2021

Accepted: September 1, 2021

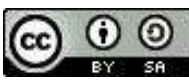

This is an open-acces article distributed under the terms of the Creative Commons Attribution-ShareAlike 4.0 International License.

\section{PENDAHULUAN}

Pandemic COVID-19 yang melanda dunia dari akhir tahun 2019 sampai saat ini, menjadi momentum yang tidak terlupakan bagi seluruh penduduk dunia. Kelumpuhan perekonomian nyaris dialami oleh semua negara, termasuk Indonesia yang dengan segala intervensi kebijakan pemerintah demi memutus mata rantai penyebaran Covid-19 ini telah menghabiskan budget trilyunan rupiah. Semua sektor kehidupan mulai dari usaha kecil masyarakat sampai industri pabrikan mengalami kemunduran dan secara langsung berdampak pada kemampuan atau daya beli masyarakat dalam memenuhi kebutuhan hidup sehari-hari. 


\section{Journal of Community Engagement in Health}

http://jceh.org

https://doi.org/10.30994/jceh.v4i2.251

ISSN: 2620-3758 (print); 2620-3766 (online)

Vol. 4 No 2. Sep 2021. Page. 363-370

Pemberlakuan Pembatasan Sosial Berskala Besar (PSBB) di akhir tahun 2020 tidak mampu menurunkan angka penderita terinfeksi virus Covid-19 secara signifikan. Saat relaksasi di masa pemberlakuan New Normal di awal tahun 2021 menyebabkan terjadinya lonjakan penderita Covid-19 dan sampai pertengahan tahun 2021, tercatat jumlah pasien positif Covid-19 bertambah 14.518 menjadi 1.066.313 kasus. Pasien sembuh bertambah 10.242 menjadi 862.502 orang. Pasien meninggal bertambah 210 menjadi 29.728 orang (Merdeka.com, 2021), sedangkan pada akhir bulan Juni 2021, terjadi lonjakan jumlah penderita yang tinggi, dengan penambahan sebesar 21.342 orang. Total akumulasi dari pertambahan orang yang terkonfirmasi positif di seluruh Indonesia menjadi sebanyak 2.115.304 orang (Merdeka.com, 2021).

Masa new normal (normal baru) adalah waktu di mana terdapat perubahan sikap atau perilaku dan gaya hidup dalam menjalankan aktivitas rutin seperti biasanya tetapi dengan menerapkan protokol kesehatan yang ketat seperti memakai masker, mencuci tangan setiap sebelum atau selesai melakukan aktivitas dan menghindari kerumunan jika tidak perlu. Perubahan perilaku hidup sehat dengan menjalankan protokol kesehatan ini menjadi kewajiban bersama baik semasih dalam masa pandemic maupun setelah pandemic berlalu. Salah satu faktor yang sangat berpengaruh terhadap kerentanan terinfeksi virus Covid-19 adalah lemahnya daya tahan tubuh (kekebalan tubuh) yang menyebabkan kondisi fisik akan menurun drastic dan mudahnya tubuh terinfeksi virus Covid-19, terutama bila memiliki riwayat kontak dengan orang-orang yang terkonfirmasi positif Covid-19 berdasarkan pemeriksaan laboratorium.

Selain kebersihan lingkungan tempat tinggal, penerapan prokes yang ketat, menjaga istrahat yang cukup serta mengkonsumsi makanan yang sehat dan bergizi adalah salah satu usaha untuk meningkatkan derajat kesehatan individu terutama selama masa pandemi maupun setelahnya. Makanan yang memiliki kelengkapan nilai gizi terutama protein, dapat meningkatkan daya tahan tubuh. Paparan atau infeksi virus dan sejumlah radikal bebas yang menyerang tubuh akan berpotensi menurunkan sistem kekebalan tubuh sehingga diperlukan senyawa-senyawa alamiah yang memiliki aktivitas antioksidan sehingga dapat mencegah atau melawan serangan dan produksi radikal bebas yang berlebihan. Dengan demikian, kerusakan pada sel imunitas dapat dicegah.

Makanan atau bahan makanan yang mengandung senyawa aktif dan memberikan manfaat yang lebih baik dan lebih banyak daripada kandungan gizi dasar dari makanan sering juga dikenal sebagai pangan fungsional. Pangan fungsional ini dapat memberikan efek yang baik terhadap peningkatan derajat kesehatan maupun mencegah penyakit. Kekerangan baik dari perairan laut maupun air tawar, merupakan salah satu sumber senyawa aktif dengan berbagai jenis bioaktivitas. Beberapa jenis senyawa fungsional kekerangan yang telah dimanfaatkan dalam bidang kesehatan antara lain adalah protein, asam lemak tak jenuh ganda (PUFAs), steroid, pigmen serta beberapa senyawa aktif berfungsi sebagai antioksidan, antivirus dan antiaging.

Tim pelaksana kegiatan dari Tim Dosen Universitas Tanjungpura, dalam usaha berpartisipasi untuk memutus rantai penyebaran Covid-19 melaksanakan tri dharma Universitas Tanjungura yang ke 3 yaitu Pengabdian kepada Masyarakat (PKM) melalui kegiatan pelatihan Peningkatan Sistem Imunitas Keluarga di Masa New Normal melalui Konsumsi Kerang-kerangan dan Diversifikasi Pengolahannya bagi Masyarakat Pantai Mutiara Desa Gunung Sembilan Kecamatan Sukadana Kabupaten Sukadana.

Tujuannya adalah mensosialisasikan olahan kerang-kerangan dan mengedukasi maryarakat tentang pentingnya mengkonsumsi pangan hasil laut sebagai salah satu usaha dalam menjaga dan meningkatkan sistem kekebalan tubuh agar tidak mudah terinfeksi virus Covid-19 ataupun infeksi penyakit lainnya. Kegiatan ini dihadiri oleh 15 peserta kegiatan, sesuai yang direncanakan. Peserta adalah perwakilan dari masing-masing RT yang diharapkan dapat menjadi duta informasi terkait dengan manfaat mengkonsumsi kekerangan.

\section{BAHAN DAN METODE}

Kegiatan PKM merupakan salah satu tri darma perguruan tinggi, usaha untuk mengimplementasikan hasil riset ataupun pengalaman akademis kepada masyarakat laus sehingga dapat bermanfaat lebih nyata dalam kehidupan bermasyarakat. Kegiatan ini didasarkan pada pertimbangan lokasi yang merupakan wilayah pesisir penghasil komoditas kekerangan tetapi umumnya masyarakat 


\section{Journal of Community Engagement in Health}

http://jceh.org

https://doi.org/10.30994/jceh.v4i2.251

ISSN: 2620-3758 (print); 2620-3766 (online)

Vol. 4 No 2. Sep 2021. Page. 363-370

belum mengenal tentang manfaat kekerangan dan bagaimana mengolahnya menjadi makanan yang menarik utuk dikonsumsi. Metode kegiatan ini adalah dengan ceramah tentang manfaat kesehatan dari beberapa jenis kerang yang dihasilkan di pantai tersebut, dan metode praktek mengolah kekerangan dalam beberapa jenis olahan.

1. Sebelum pelaksanaan kegiatan, tim pelaksana berkoordinasi dengan masyarakat setempat selanjutnya melakukan perizinan kepada pemerintah setempat dan menentukan jadwal pelaksanaan kegiatan serta daftar undangan. Tahapan ini dilakukan secara daring, mengingat suasana masih dalam PPKM. Selanjutnya adalah penyiapan peralatan dan bahan seperti bumbubumbu bawang merah, bawang putih, cabe rawit, cabe besar, jahe, lengkuas, serai, ketumbar, merica, sayuran buncis, kol, seledri, asam jawa, gula merah, tusuk sate, wajan, sudet, wadah tirisan, gunting, kompor, piring, sarung tangan, dan perlengkapan lainnya.

2. Pelaksanaan kegiatan yang meliputi ceramah tentang edukasi manfaat kesehatan dalam mengkonsumsi kekerangan yang dilanjutkan dengan praktek pembuatan aneka olahan makanan yang berbahan dasar kerang-kerangan. Kegiatan ini diikuti oleh 15 orang peserta yang terdiri dari ibu-ibu dan remaja putri.

3. Akhir dari rangkaian kegiatan PKM ini adalah melakukan evaluasi dan monitoring kemajuan dari kegiatan yang telah dilaksanakan.

\section{HASIL}

Pelaksanaan kegiatan PKM tentang Peningkatan Sistem Imunitas Keluarga di Masa New Normal melalui Konsumsi Kerang-kerangan dan Diversifikasi Pengolahannya di wilayah Pantai Mutiara dilaksanakan pada tanggal 21 Agustus 2021 sebagai salah satu usaha dan peranserta tim pelaksana dalam meningkatkan kesehatan individu dan masyarakat di pesisir Pantai Mutiara selama pandemic dan persiapan menghadapi masa new normal. Kegiatan ini dilaksanakan secara offline dengan tetap mematuhi prokes sebagai proteksi dan pemutusan rantai penyebaran Covid-19.
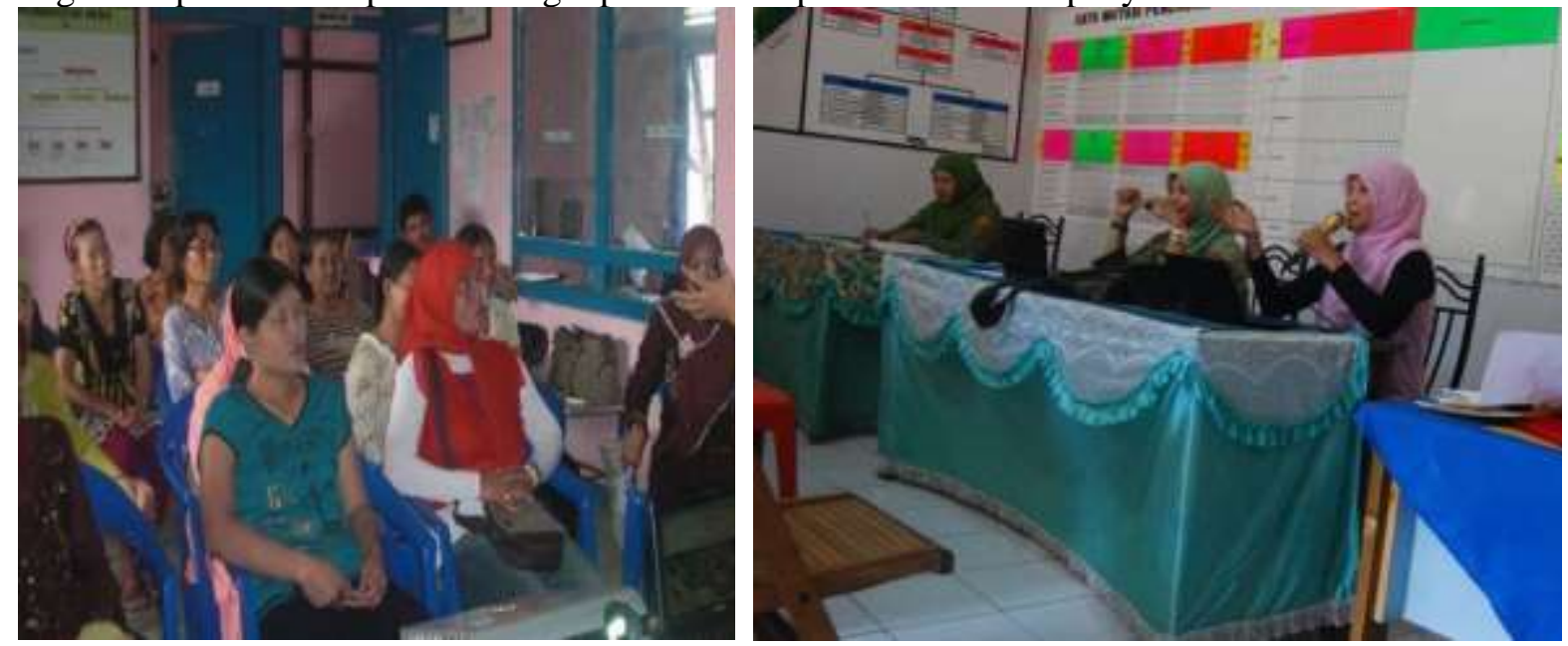

Gambar 1. Ceramah edukasi manfaat kesehatan dari kekerangan 


\section{Journal of Community Engagement in Health}

http://jceh.org

ISSN: 2620-3758 (print); 2620-3766 (online) https://doi.org/10.30994/jceh.v4i2.251

Vol. 4 No 2. Sep 2021. Page. 363-370
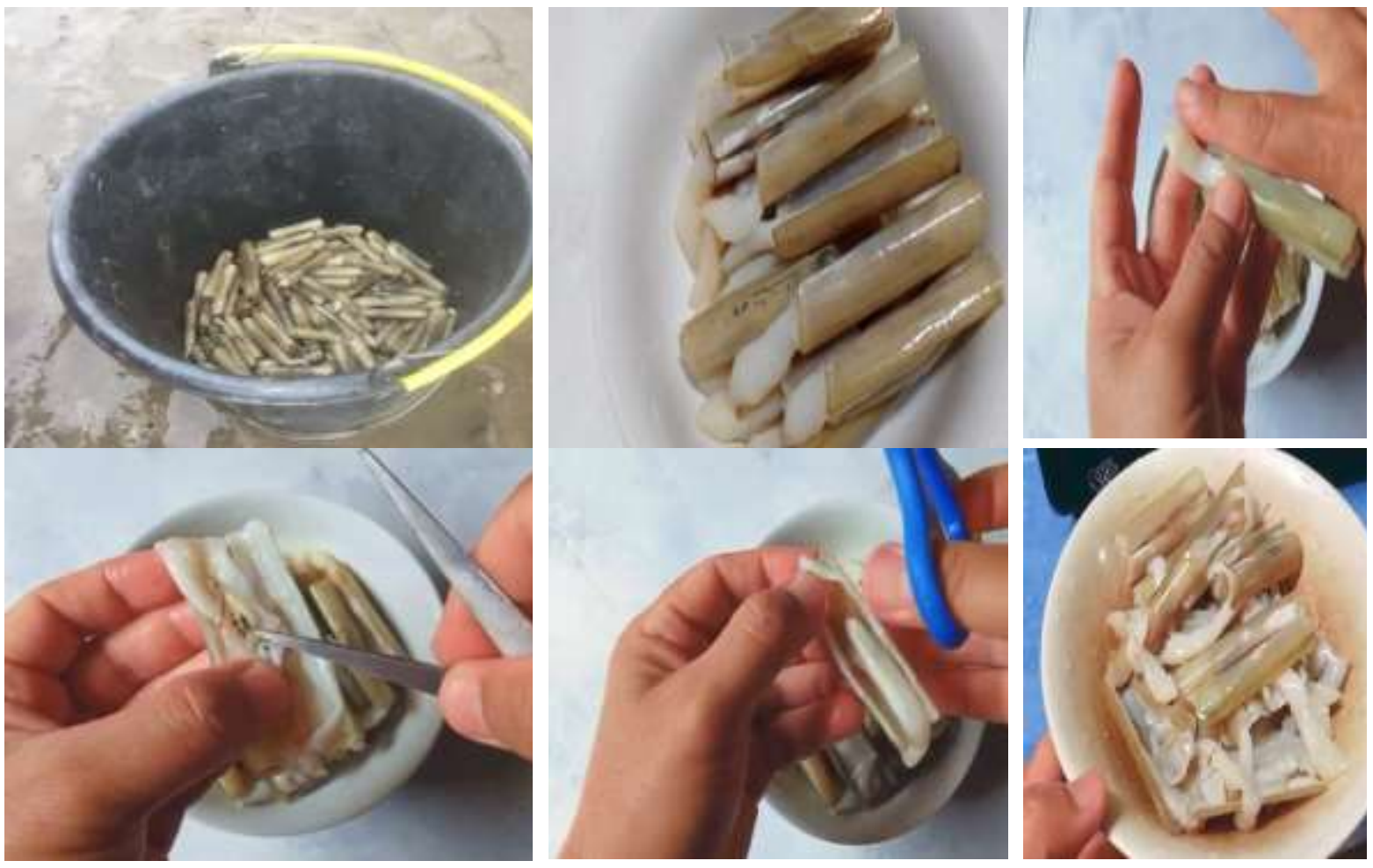

Gambar 2. Salah satu cara membersihan kerang (Solen sp)
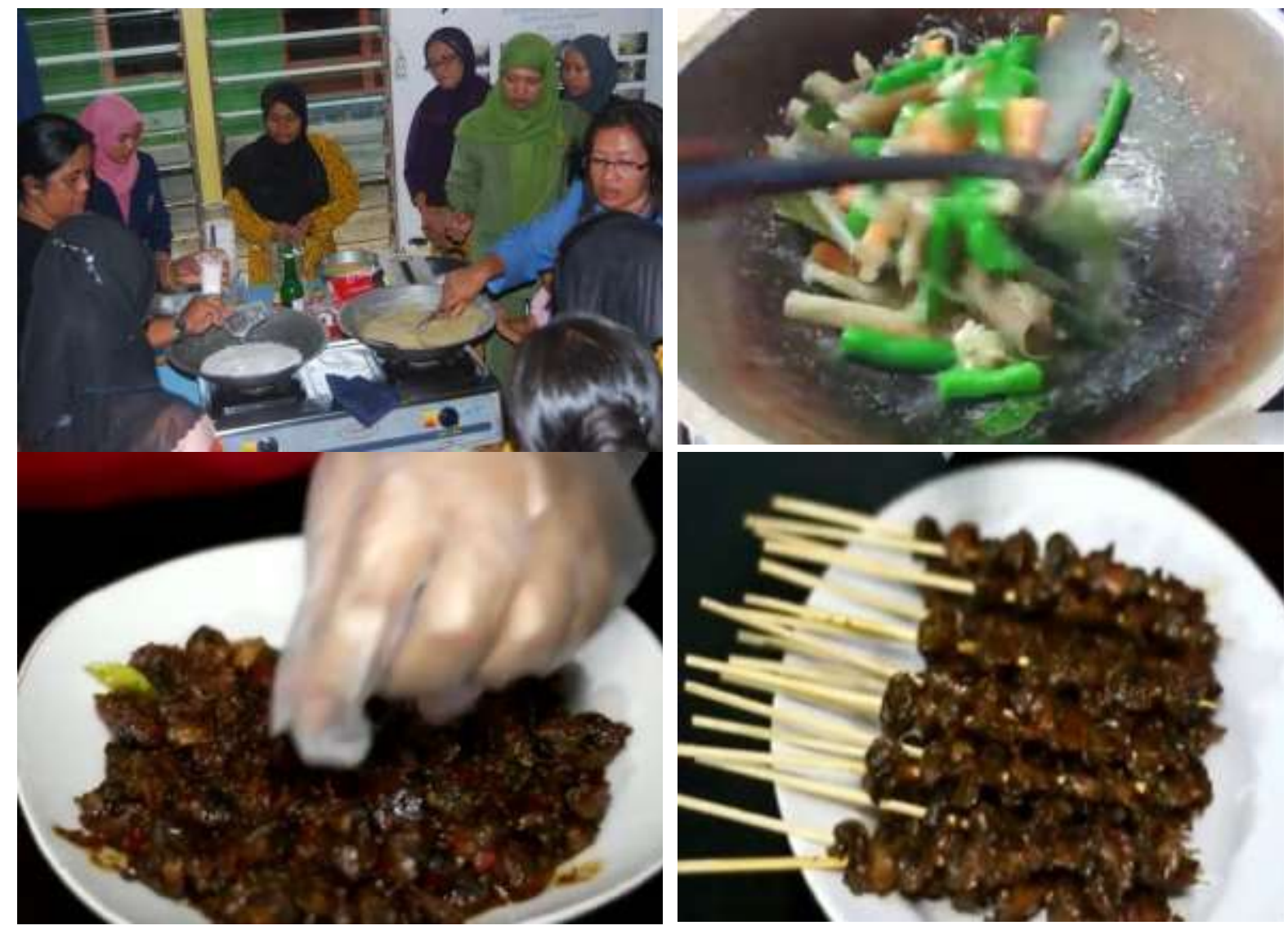

Gambar 3. Beberapa jenis olahan kekerangan kerang darah dan kerang bambu 


\section{Journal of Community Engagement in Health}

http://jceh.org

https://doi.org/10.30994/jceh.v4i2.251

ISSN: 2620-3758 (print); 2620-3766 (online)

Vol. 4 No 2. Sep 2021. Page. 363-370

Kegiatan ini difokuskan pada pengolahan kerang darah dan kerang bambu, karena keduanya memiliki kelimpahan yang besar di pantai Mutiara Kayong Utara. Pelatihan ini dipraktekkan cara-cara membersihkan kerang kepada masyarakat, sehingga daging kerang yang dimakan bersih dan lebih menarik jika dipasarkan.

Adapun resep pengolahan kerang dalam kegiatan ini antara lain adalah :

1. Sate Kerang Darah

Bahan kerang darah 350 gram

Kerang darah dibersihkan, kemudian direbus dan dipisahkan cangkangnya.

Bumbu dihaluskan : 6 biji bawang merah, 6 siung bawang putih, 3 biji cabe keriting, 6 biji cabe rawit, $1 / 2$ sendok makan ketumbar bubuk, 1 sendok teh merica bubuk.

Rempah yang digeprek atau dicincang kasar: Sejari jahe, 2 batang sereh.

Bumbu halus ditumis, kemudian daging kerang darah dimasukkan ke dalam bumbu tumis, tambahkan rempah yang digeprek, 1 sendok makan gula merah, 1 sendok makan air asam jawa dan 1 sedok makan kecap manis, kemudian dididihkan sampai bumbunya meresap, kuah mengental sampai kering. Selanjutnya ditusuk dengan tusuk sate, dapat dihidangkan langsung atau terlebih dahulu dipanggang. Dapat dimakan dengan atau tanpa sambal kacang.

2. Kerang Bambu saus tiram

Bahan kerang bambu 350 gram

Bumbu digeprek dan dicincang kasar : 3 siung bawang putih, $5 \mathrm{~cm}$ jahe dimemarkan, 3 sendok makan saus tiram, 2 sendok makan kecap manis, 1/2 sendok teh garam, 1/2 sendok teh merica bubuk, 150 gram jamur kancing, 1/2 buah bawang bombai diiris. Bawang putih, bawang bombay dan jahe ditumis hingga harum, kemudian ke dalamnya dimasukkan kerang bambu, saus tiram dan kecap manis, garam, merica, dan kemudian aduk rata lalu dimasak sampai matang. bawang bombai, masak sebentar lalu diangkat dan dihidangkan. Evaluasi kegiatan pelatihan ini dapat diketahui berdasarkan meningkatnya pemahaman peserta terkait manfaat kekerangan dan beberapa cara pengolahan kerang yang telah disampaikan oleh pemateri sekaligus telah dipraktekkan bersama.

\section{PEMBAHASAN}

Pandemi Covid-19 telah berdampak kuat pada daya beli masyarakatm sehingga secara langsung pola makan msyarakat ikut terdampak kuat. Keadaan selama masa pandemic dan persiapan menghadapi new normal berikutnya telah menuntut kita untuk dapat menjaga imunitas tubuh kita dari serangan infeksi virus ataupun mikroorganisme lainnya melalui konsumsi pangan sehat dan bergizi gizi tinggi, dengan demikian dapat menurunkan resiko ikut terpaparnya atau terinfeksi dengan wabah penyakit.

Materi ceramah yang disampaikan sebagai bentuk edukasi tim pelaksana kepada masyarakat pantai Mutiara antara lain adalah manfaat dari mengkonsumsi kerang terhadap kesehatan kita terutama dalam meningkatkan kekebalan tubuh dari berbagai serangan infeksi penyakit termasuk mencegah terjangkitnya penyakit Covid-19 Nilai gizi kandungan dari bahan makanan ataupun dalam bentuk produk hasil olahannya sangat penting peranannya dalam sistem imunitas tubuh. Konsumsi bahan makanan dengan kandungan zat gizi makro maupun zar gizi mikro menyebabkan terjadinya aktivasi sistem kekebalan tubuh (Virralluel-Lopez et al. 2017). Menurut Mosca et al (2015) dan Maina (2018) tentang sangat pentingnya mengkonsumsi pangan fungsional baik dikonsumsi rutin ataupun secara periodic yang dimaksudkan untuk dapat meningkatkan derajat kesehatan dan usaha mencegah diri dari terjangkitnya suatu. Pangan fungsional adalah makanan atau bahan pangan yang memiliki kandungan senyawa aktif dan dapat bermanfaat terhadap pencapaian kualitas kesehatan yang optimal sehingga sekaligus dapat mengurangi resiko terpapar suatu penyakit (Mosca et al. 2015; Maina, 2018).

Kekerangan merupakan salah satu anggota dari suku Bivalvia ataupun gastropoda yang termasuk dalam kelas Molusca atau hewan bertubuh lunak. Keberadaanya di perairan baik perairan air laut maupun air tawar, selain sebagai unsur bioekologi atau biota yng memiliki fungsi ekologi di dalam suatu ekosistem, juga merupakan salah satu sumber pangan perairan terlezat dengan kandungan gizi yang beraneka ragam dan menjadikannya sebagai target berburu kuliner seafood yang tergolong sukup mahal sehingga menjadi konsumsi masuarakat kelas menengah ke atas. 


\section{Journal of Community Engagement in Health}

http://jceh.org

https://doi.org/10.30994/jceh.v4i2.251

ISSN: 2620-3758 (print); 2620-3766 (online)

Vol. 4 No 2. Sep 2021. Page. 363-370

Kekayaan akan kandungan gizi dalam kerang sebenarnya kurang lebih sama dengan kandungan bioaktivitas biota laut lainnya. Adapun kandungan gizi makro yang terdapat dalam kekerangan antara lain adalah protein, karbohidrat dan lemak (Rusyadi, 2006). Supriyantini (2007) melaporkan bahwa kerang merupakah sumber protein hewani laut yang utama, tergolong sebagai biota kaya dengan Complete Protein, disebabkan oleh kandungan asam amino essensialnya yang sangat tinggi (yaitu antara $85 \%-95 \%$ ). Jumlahnya asam amino yang paling tinggi di mana dalam setiap 100 gram daging kekerangan mengandung glutamate sebesar $3.474 \mathrm{mg}$, aspartat sebesar $2.464 \mathrm{mg}$, lysine sebesar 1.909 $\mathrm{mg}$, arginin sebesar $1.864 \mathrm{mg}$ dan leusin sebesar 1.798. Selain itu kekerangan pun memiliki kandungan vitamin B12 yang tinggi dengan besaran nilai sekitar $98.9 \mathrm{mg} / 100 \mathrm{mg}$. Kandungan vitamin B12 dalam kerang sangat berguna dalam memelihara fungsi dan kesehatan jantung, menjaga kestabilan temperature tubuh, menjaga kestabilan $\mathrm{pH}$ tubuh, serta membantu mencernakan makanan dan meningkatkan fungsi sistem syaraf dan mensupport proses pembentukan dan pemeliharaan sel tulang.

Umumnya daging kekerangan memiliki kelimpahan kandungan asam lemak omega-3 dan omega-6, dengan konversi energi sekitar 59 kilokalori. Kelimpahan kandungan protein dalam kerang pada umumnya sekitar 8 gram. Protein memiliki peran penting dalam proses pembentukan enzim atau hormon dalam tubuh, mengepitelisasi sel yang rusak terutama dalam pemulihan selama atau setelah terpapar penyakit, membentuk sel organ dan otot yang baru, memulihkan sel-sel yang menggalami kerusakan dalam tubuh, memperbaiki system metabolisme tubuh serta menjaga dan meningkatkan sistem kekebalan tubuh terutama dalam masa adanya wabah penyakit. Kandungan gizi karbohidrat dalam kekerangan sekitar 3,6 gram, lemak sebesar 1,1 gram, kandungan kalsium sebesar 133 miligram, dan kandungan fosfor sebesar 170 miligram, serta zat besi adalah sebesar 3 miligram. Selain kandungan gizi makro, kekerangan juga mengandung vitamin A sebesar 300 IU, vitamin B1 sebesar 0,01 miligram dan vitamin $C$ sebesar 0,01 miligram. Mineral yang terkandung dalam kerang antara lain adalah zat besi sebesar $28 \mathrm{mg} / 100 \mathrm{gr}$ sebagai komponen mineral tertinggi dan selenium dengan kandungan sebesar $64 \mathrm{mg} / 100$ gr. Kandungan zat besi pada kekerangan pada umumnya sangat berguna dalam pembentukan sel-sel darah merah dalam tubuh, yang secara signifikan dapat menurunkan resiko tekanan darah rendah, serta dapat mencegah anemia. Kandungan mineral lainnya adalah Selenium memiliki peran sebagai penangkal radikal bebas yang menyebabkan berbagai infeksi penyakit seperti kanker dan penyakit degenerative lainnya (Pancapalaga. 2005).

Masyarakat sangat antusias mengikuti edukasi ini, kemudian dilanjutkan dengan pemaparan tim pelaksana terkait beberapa cara pengolahan kerang yang dapat menstimulus selera makan buat keluarga. Selama ini konsumsi kekerangan di kalangan masyarakat pesisir pantai Mutiara sangat kurang meskipun kelimpahan kerang dan diversitas kerangnya termasuk cukup tinggi di wilayah tersebut. Kerang darah (Anadara granosa), remis (Meretrix sp) dan kerang bambu (Solen $\mathrm{sp}$ ) merupakan salah satu jenis kekerangan yang melimpah dari pantai tersebut, didukung oleh pantai berlumpur serta terjadinya surut yang sangat kuat secara periodik di perairan tersebut. Praktek membuat masakan olahan dari kerang darah dan kerang bambu sangat menarik minat masyarakat.

Evaluasi materi kegiatan yang disampaikan dilakukan melalui test angket atau pretest dan posttest yang dibagikan kepada peserta di awal dan di akhir acara kegiatan. Dari 15 peserta pelatihan yang hadir semuanya turut berpartisipasi dalam menyampaikan jawaban pretest dan posttest. Evaluasi kegiatan ini menunjukkan kemajuan yang sangat bagus di mana ada indikasi terjadi peningkatan pemahaman dan pengetahuan peserta terkait materi manfaat kesehatan dari mengkonsumsi kekerangan, dari persentase di awal hanya sebesar 30-45\% menjadi persentase 80-90\%. Bahkan dalam akhir kegiatan masyarakat berharap adanya kegiatan lagi yang dapat meningkatkan keterampilan mengolah kerang dalam usaha menjadikannya sebagai usaha home industry. 


\section{Journal of Community Engagement in Health}

http://jceh.org

https://doi.org/10.30994/jceh.v4i2.251

ISSN: 2620-3758 (print); 2620-3766 (online)

Vol. 4 No 2. Sep 2021. Page. 363-370

Tabel 1. Persentase jawaban peserta pelatihan berdasarkan kuisioner yang dibagikan

\begin{tabular}{|c|c|c|c|c|c|}
\hline \multirow[t]{2}{*}{ No } & \multirow[t]{2}{*}{ Soal } & \multicolumn{2}{|c|}{ pre test } & \multicolumn{2}{|c|}{ post test } \\
\hline & & Ya & Tidak & Ya & Tidak \\
\hline 1 & $\begin{array}{l}\text { Apakah anda pernah membaca tentang } \\
\text { pangan fungsional? }\end{array}$ & $45 \%$ & $55 \%$ & $100 \%$ & - \\
\hline 2 & $\begin{array}{l}\text { Apakah anda memahami bahwa } \\
\text { kekerangan berbagai jenisnya baik dari } \\
\text { perairan tawar ataupun perairan laut } \\
\text { sangat kaya dengan senyawa bioaktif? }\end{array}$ & $30 \%$ & $70 \%$ & $90 \%$ & 10 \\
\hline 3 & $\begin{array}{l}\text { Apakah anda mengetahui bahwa } \\
\text { kekerangan memiliki kandungan protein, } \\
\text { asam } 2 \text { amino serta asam lemak omega } 3 \\
\text { dan omega } 6 \text { ? }\end{array}$ & $45 \%$ & $55 \%$ & $90 \%$ & $10 \%$ \\
\hline 4 & $\begin{array}{l}\text { Apakah anda familiar mengkonsumsi } \\
\text { kekerangan dalam menu makanan di } \\
\text { rumah? }\end{array}$ & $30 \%$ & $70 \%$ & $50 \%$ & $50 \%$ \\
\hline 5 & $\begin{array}{l}\text { Apakah anda mengetahui bahwa } \\
\text { kandungan aktif dari kekerangan dapat } \\
\text { menjaga system imunitas tubuh sehingga } \\
\text { dapat melindungu dari infeksi penyakit? }\end{array}$ & $30 \%$ & $70 \%$ & $90 \%$ & 10 \\
\hline 6 & $\begin{array}{l}\text { Apakah anda mengetahui bahwa dengan } \\
\text { mengkonsumsi kekerangan pada } \\
\text { umumnya dapat melindungi tubuh kita } \\
\text { dari infeksi virus COVID19? }\end{array}$ & $30 \%$ & $70 \%$ & $90 \%$ & 10 \\
\hline 7 & $\begin{array}{l}\text { Apakah kegiatan pelatihan ini dapat } \\
\text { meningkatkan pengetahuan anda tentang } \\
\text { pangan fungsional dari laut? }\end{array}$ & $75 \%$ & $25 \%$ & $100 \%$ & - \\
\hline
\end{tabular}

\section{KESIMPULAN}

Dari hasil kegiatan PKM ini menunjukkan meningkatnya pemahaman masyarakat tentang efek kesehatan dari mengkonsumsi kekerangam serta kemampuan keterampilan masyarakat dalam mengolah pangan dari kekerangan laut asal Pantai Mutiara. Pemahaman tentang kekerangan sebagai pangan fungsional dari peserta pelatihan meningkat dari 30-45\% menjadi $80-90 \%$, suatu indikasi yang menunjukkan antusiasme dan perhatian penuh dari masyarakat selama kegiatan ini berlangsung.

\section{REFERENSI}

Kompas. (2020). Resep Kerang bambu ala restoran seafood. Diunduh pada Agustus 2021 dari https://www.kompas.com/food/read/2020/08/21/110100075/resep-kerang-bambu-jamur-saustiram-makan-ala-restoran-seafood

Merdeka. (2021). Peristiwa update data Covid-19 di Indonesia. Diunduh pada 27 Juni 2021 dari https://www.merdeka.com/peristiwa/update-data-covid-19-di-indonesia-per-27-juni-2021.html

Maina, J.,W., (2018). Analysis of the factors that determine food acceptability. The Pharma Innovation Journal. 7(5): 253-257.

Mosca, A.,C., Van, D.,V.,F., Bult, J.,H., Boekel, M.,A., Stieger, M, (2015). Taste enhancement in food gels: Effect of fracture properties on oral breakdown, bolus formation and sweetness intensity. Food Hydrocolloids. 43:794-802.

Pancapalapa, W., (2005). Pengaruh Pemberian Kaldu Kupang Terhadap Kualitas Gizi Dan Sensori Kerupuk Kupang. Skripsi. Jurusan Teknologi Industri Peternakan-Fakultas Peternakan Perikanan-Universitas Muhamadiyah Malang.

Rusyadi, S., (2006). Karakter Gizi Dan Potensi Pengembangan Kerang Pisau Solen sp. Skripsi. Fakultas Perikanan dan Ilmu Kelautan-Universitas Muhamadiyah. Malang 


\section{Journal of Community Engagement in Health}

http://jceh.org

https://doi.org/10.30994/jceh.v4i2.251

ISSN: 2620-3758 (print); 2620-3766 (online)

Vol. 4 No 2. Sep 2021. Page. 363-370

Supriyantini, E., (2007). Kandungan Asam Lemak Omega 3 (Asam Linolenat) Pada Kerang Totok Polimesoda yang Diberi Pakan Tetraselmis Chui dan Skeletonema. Skripsi. Fakultas Perikanan dan Ilmu Kelautan-IPB. Bogor.

Virralluel-lopez, A., Ascencio, F.,N.,K., (2017). Microalga, potential natural functional food source-a Review. Polish Journal of Food and Nutrition Science. 67(4): 251-263. 